ISSN 0258-7122

Bangladesh J. Agril. Res. 37(3): 473-491, September 2012

\title{
ECONOMIC ANALYSIS OF RISKS IN FRUIT AND VEGETABLE FARMING IN OSUN STATE, NIGERIA
}

\author{
S. B. FAKAYODE, M. A.Y. RAHJI AND S. T.ADENIYI
}

\begin{abstract}
The study analyzed the risks involved in fruit and vegetable farming in Osun state, Nigeria. Specifically, the study examined the risk attitude of farmers, factors influencing risk attitude as well as farmer's perception on major sources of production and market risks. The study was based on a survey of 150 farmers, comprising 75 predominantly fruit and vegetable farmers, respectively, and covering 12 communities within the six agro-ecological zones in the state. Data were collected using a well structured questionnaire. Descriptive statistics, discriminant analysis and Kruskal-Wallis ranking analysis were used in the study. The study revealed that the average age of the fruit and vegetable respondent was 58.5 and 40.1, respectively, with the male respondents outnumbering the females in each case. The average year of experience was 30.8 and 15.3 for fruit and vegetable respondent, respectively. An average area of (5.36 and 2.21) ha was cultivated by the fruit and vegetable farmers, while orange and okra are the most widely grown fruit and vegetable crops. Damage by pest and disease, traditional methods of farming and weather dependency were the most perceived sources of production risk by the fruit and vegetable farmers. Perishability of produce, low price of produce, poor product handling and packaging as well as exploitation by middlemen were the most perceived sources of market risk. The study also revealed that maintaining good relationship with traders, selling at low prices due to perishability, selling within the locality and non-farm businesses were the major risk management strategies employed by the farmers. Based on the study findings, it is recommended that introduction of a more comprehensive agricultural insurance scheme and introduction of improved technology can ameliorate the effect of risks on fruit and vegetable farmers. Also, public intervention can facilitate better risk management through improved information system.
\end{abstract}

Keywords: discriminant analysis, Kruskal-wallis ranking analysis, risk, fruit, vegetable.

\section{Introduction}

Agriculture is considered the largest sector in Nigeria's economy. It employs 70 percent of the nation's labour force, contributes at least 40 percent of the gross domestic product and accounts for over three-quarters of the non-oil foreign exchange earnings (Ajekigbe, 2007). Nigeria's abundant land resources and wide variety of climate variations allows it to produce a variety of food and cash crops.

Department of Agricultural Economics and Farm Management, P.M.B 1515, University of Ilorin, Ilorin, Nigeria 
These stable food crops include cassava, yam, cocoyam, maize, beans, sweet potato, millet, rice, sorghum and a variety of fruits and vegetables. The leading cash crops are cocoa, groundnut, palm oil and rubber. These crops were also Nigeria's major exports in the 1960s and early 1970s (U.S. Library of Congress, 2009).

In spite of various initiatives aimed at improving the agricultural sector which includes the horticultural sub-sector, the sector still remains relatively under-developed. The horticultural sub-sector also reflects the problems in the agricultural sub-sector. These problems include inadequate knowledge and technology of production, insufficient planting materials, land tenure, poor extension services and insufficient post harvest facilities (Babatola, 2004). Horticultural crop production in Nigeria has been hampered by the policy and fiscal constraints of the governments. It has received very little attention in the national perspective plan for agricultural development (Oseni, 2004). In addition, Nigeria has only one research institute, National Horticultural Research Institute (NIHORT) established in 1975 for all horticultural crops. Horticultural crop farming is associated with negative outcomes stemming from imperfect predictable biological, climatic and price variables. Those variables include natural adversities e.g. pest and diseases, weather factors not within the control of agricultural producers and adverse fluctuations in both input and output prices. In the light of the foregoing, this study examines the risks and other related factors associated with fruit and vegetable farming.

Given the low level of consumption of fruits and vegetables in Nigeria, the greatest challenge is how to devise the means for improving the production and supply chains of these commodities. This will in turn lower prices and raise incomes. It would also expand, diversify and stabilize supplies thus, ensuring food safety and increasing the desirability of fruits and vegetables. However, the production and marketing of these commodities take place in an environment characterized by highly variable biophysical, economic, political and institutional conditions, which poses several types of risk. It is also important to note that, risk perceptions generally play key roles in the production, investment and marketing behaviour of farmers. Despite this, only limited attention has been paid to understanding the nature and distribution of risks in practices involving fruit and vegetable farming.

The foregoing discussion, therefore, raises the following research questions:

- What is the attitude of farmers towards the risks in fruit and vegetable farming?

- What are the production resources used in fruit and vegetable farming?

- What are the factors influencing farmers' attitude towards the risks in fruit and vegetable farming? 
- What are the perception of farmers on major sources of risk in fruit and vegetable farming?

- What are the strategies of farmers at combating the risks in fruits and vegetable farming?

This study, therefore, seeks to provide answers to these pertinent questions.

\section{Objective of the study}

The main objective of the study was to analyze the risks involved in fruit and vegetable farming in Osun State, Nigeria. The specific objectives were to:

(i) examine the socio-economic characteristics of fruit and vegetable farmer.

(ii) determine the production resources in fruit and vegetable fruit and vegetable farming?

(iii) determine the risk attitude of fruit and vegetable farmer;

(iv) examine the factors influencing the farmer's attitude towards the risks in fruit and vegetable farming;

(v) assess farmer's perception on major sources of risk in fruit and vegetable farming;

(vi) profile farmer's strategies at combating the risks associated with fruit and vegetable farming.

\section{Fruits and vegetables production in Nigeria: An overview}

Major fruits produced in Nigeria include mango, pineapple, plantain/banana, citrus, guava, pawpaw, while vegetables include onion, tomato, okra, pepper, amaranthus, carrot, melon, Corchorus olitorus (ewedu), Hibiscus sabdariffa (sobo), Adansonia digtata (baobab leaves). While most tropical fruits, vegetables and ornamentals will thrive in Nigeria, a combination of agro-ecological limitations and socio-economic considerations have lead to a short-listing and clustering of fruits and vegetables in the wild that is almost impossible to make obtainable in Nigeria.

In spite of the enormous potentials of most of our local fruits and vegetables for industrial growth and development, very few large scale fruit and vegetable processing industries abound in Nigeria. Besides, the number of small and medium scale fruit processing plants in the country neither watches the size and structure of the country nor project the potentialities of the various and varieties of fruit and vegetables grown in the country. According to Asoegwu (1989), surveys show that the some horticultural crops or their derivatives form the main raw materials for most of the fruits and vegetables processing industries in Nigeria. These fruits include citrus, pineapple, mango and plantain/banana, while 
the vegetables include tomatoes, pepper, and melon. Yet the number of fruits and vegetables identified with useful industrial potential are handful. Also, aside, solving the problems of shortages and malnutrition, postharvest conservation and processing, the establishment of industries dealing with fruits and vegetables will stimulate production open new opportunities for investment, improve rural income and result in better quality food (Adeyemi and Ogazi, 1983).

The industrial potential of many fruits and vegetables available in Nigeria is enormous. What Nigerians need to do is embark on massive production of these fruits and vegetables not only for their high nutritive value but for enhancing the establishment of many processing industries. The development of their industrial uses will stimulate large scale production of the crops and enhanced diversification of entrepreneur to site processing plants in the rural areas which will improve the quality of life of the rural population and reduce the rate of rural-urban migration (Ullah, 1980). He further stated that the backward integration policy of the government should be vigorously pursued especially in the fruits and vegetables processing because of their enormous industrial potential.

\section{Methodology}

\section{Study area and data}

The study was conducted in Osun state, Nigeria. The state lies between latitude $7^{\circ} 30^{\prime} \mathrm{N}$ of the equator and longitude $4^{\circ} 30^{\prime} \mathrm{E}$ of the Greenwich meridian on a land area of about 9,251 $\mathrm{km}^{2}$ (Atlas, 2006). The state shares boundaries with Kwara state in the North, Oyo state in the West, Ogun state in the South, and Ondo and Ekiti states in the East. It comprises 30 local government areas.

According to the 2006 census reports, the population of Osun state stood at about 4.14 million consisting of the Yoruba ethnic group. Over 90 percent of the rural populace are involved in farming. Important towns and cities in the state include Osogbo, which is the state capital city as well as the ancient kingdom capitals of Ile-Ife, Oke-Ila Orangun, Ila Orangun, Ede and Ilesha (Wikipedia, 2009).

The state has 2 distinct climatic seasons, namely the dry and wet season. The natural vegetation comprises moist evergreen and semi-evergreen forest and secondary forest, with mean annual rainfall ranging between 1400 to $2000 \mathrm{~mm}$. Mean annual temperature ranges between 26 to $27^{\circ} \mathrm{C}$ (Atlas, 2006). Crops produced in the state include cash crops including cocoa, oil palm, kola and food crops including cassava, yam, maize and some fruits and vegetables. Major fruits produced in the state include oranges, grape, lemon, tangerine, plantain/banana, mango, pineapple, pawpaw, walnut, albidium(agbalumo), chrysophyllum, Invingia gabonensis. Major vegetables include pepper, tomato, amaranthus (tete), 
okra, melon (Celocynthis citrulus), water leaf (talinum), bitter leaf, Egg plant fluted pumpkin (Telfaria occidentalis), sokoyokoto(Celostia argenta), ewedu (Corchorus olitorus) (Osun state, 2009).

Osun state is classified into six (6) agro-ecological zones by the Osun State Agricultural Development Programme (OSSADEP).

The target population for this study was the fruit and vegetable farmers across Osun State. A two stage sampling technique was adopted for this study. The first stage involved the selection of twelve (12) communities (6 fruits and 6 vegetables producing communities). Two (2) communities were selected from each of the six (6) Agricultural Development Project (ADP) zones in the state. The second stage involved a random selection of 150 respondents; 75 fruit farmers from six selected fruit producing communities and 75 vegetable farmers from six selected vegetable producing communities.

Table 1. Sample design outlay for the study.

\begin{tabular}{llllll}
\hline \multirow{2}{*}{ ADP Zone } & \multicolumn{2}{|c|}{ Fruit community } & $\begin{array}{c}\text { No. of } \\
\text { Respondents }\end{array}$ & Vegetable community & $\begin{array}{c}\text { No of } \\
\text { Respondents }\end{array}$ \\
\hline Ede & Sekona & 12 & Ede & 13 \\
Ife & Edunabon & 13 & Olagiri & 12 \\
Ilesha & Iperindo & 13 & Ilesha & 12 \\
Ikirun & Oke-Ila Orogun & 12 & Ora & 13 \\
Iwo & Ogbaabga & 12 & Iwo & 13 \\
Osogob & Ilie & 13 & Osogbo & 12 \\
\hline Total & $\mathbf{6}$ & $\mathbf{7 5}$ & $\mathbf{6}$ & $\mathbf{7 5}$
\end{tabular}

Source: Field Survey, 2010

\section{Analytical tools}

The following tools were employed in the analysis of the data collected; Descriptive Statistical Analysis, Discriminant Analysis and Kruskal-wallis One Way Analysis of Variance (ANOVA) by Ranks.

\section{Descriptive statistical analysis}

Descriptive statistical analysis was used to examine the socio-economic characteristics of fruit and vegetable farmer, determine the production resources in fruit and vegetable fruit and vegetable farming and assess farmer's perception on major sources of risk in fruit and vegetable farming (objectives 1, 2 and 6 of the study). The descriptive statistical tools that were employed include; percentage, frequency distribution, mean, mode, coefficient of variation and standard deviation. These tools were used to analyze the socio-economic 
characteristics of the respondents as well as to examine the types of fruits and vegetables grown, their production practices, cropping patterns and income distribution. These tools were also used to profile farmers' strategies at combating risks in fruit and vegetable farming.

\section{Discriminant analysis}

Discriminant analysis was used to determine the risk attitude of fruit and vegetable farmer and examine the factors influencing the farmer's attitude towards the risks in fruit and vegetable farming (objectives 3 and 4 of the study). Discriminant analysis is a statistical technique to classify objects or individuals into mutually exclusive and exhaustive groups based on a set of measurable features that describe the objects or individuals. In general, we assign an object to one of a number of pre-determine groups based on observations made on the object (Teknomo, 2006).

Discriminant analysis requires a nominal dependent variable and independent variables that could either be nominal, ordinal, interval or ratio (Klecka, 1980). Therefore, discriminant analysis was conducted to explore quantitatively the relationship between farmer's attitude towards risk and factors influencing this attitude in fruit and vegetable farming. Salau (2009) used discriminant analysis to determine the factors influencing the risk attitude of farmers in maize farming.

For the nominal dependent variables, farmers were classified into 3 groups as follows:

- Group 1 - Risk Averse

- Group 2 - Risk Neutral

- Group 3 - Risk Taker

The independent variables which consists of socio-economic and farm characteristics are defined as follows:

- $\mathrm{X} 1$ - Experience (years)

- X2 - Education status

- X3 - Household size

- X4 - Total area of land cultivated (ha)

- X5 - Other sources of income (yes or no)

- X6 - Membership of association (yes or no)

- X7 - Total estimated expenditure per month (Naira)

- X8 - Proportion of farm income to total income

- $\quad$ X9 - Availability of storage facilities (yes or no)

- X10 - Gender 


\section{Kruskal-Wallis one way analysis of variance (ANOVA) by ranks}

Kruskal-Wallis ranking analysis was used to assess farmer's perception on major sources of risk in fruit and vegetable farming (objective 5 of the study). This tool was used to measure the responses gathered from farmer's perception on sources of risks associated with fruit and vegetable farming. Fakayode et al, (2009) used Kruskal-Wallis One Way Analysis of Variance (ANOVA) by Ranks to assign priorities to identified constraints to Apiculture.

The equation for estimating the ranks is outlined thus:

$\mathrm{H}=\frac{12}{(N+1)} \sum_{i=1}^{n i} \frac{1}{n i} \frac{\left[R i-n i(N+1)^{2}\right.}{2}$

Where $\mathrm{Ri}$, is the sum of the ranks assigned to observation in the ith sample and $\frac{n i(N+1)}{2}$,the expected sum of ranks for the ith treatment (Wayne, 1990).

\section{Results and Discussion}

\section{Socio-economic characteristics of the respondents}

The socio-economic characteristics as shown in Table 2 are expected to play important roles in the economic performance of the fruit and vegetable respondents.

Table 2. Socio-economic characteristics of respondent farmers.

\begin{tabular}{|c|c|c|c|c|}
\hline \multirow{2}{*}{ Characteristics } & \multicolumn{2}{|c|}{ Fruit } & \multicolumn{2}{|c|}{ Vegetable } \\
\hline & Frequency & Percentage & Frequency & Percentage \\
\hline \multicolumn{5}{|l|}{ Gender } \\
\hline Male & 62 & 82.7 & 53 & 70.7 \\
\hline Female & 13 & 7.3 & 22 & 29.3 \\
\hline Total & 75 & 100 & 75 & 100 \\
\hline \multicolumn{5}{|l|}{ Marital status } \\
\hline Single & 7 & 9.3 & 17 & 22.7 \\
\hline Married & 68 & 90.7 & 58 & 77.3 \\
\hline Total & 75 & 100 & 75 & 100 \\
\hline \multicolumn{5}{|l|}{ Age group (years) } \\
\hline $21-40$ & 8 & 10.7 & 46 & 61.3 \\
\hline $41-60$ & 34 & 45.3 & 22 & 29.4 \\
\hline $61-80$ & 28 & 37 & 7 & 9.3 \\
\hline $81-100$ & 5 & 7 & - & - \\
\hline Total & 75 & 100 & 75 & 100 \\
\hline
\end{tabular}


Table 2. Cont'd.

\begin{tabular}{|c|c|c|c|c|}
\hline \multicolumn{5}{|l|}{ Education } \\
\hline Primary & 23 & 30.7 & 7 & 9.3 \\
\hline Secondary & 22 & 29.3 & 38 & 50.7 \\
\hline Tertiary & 4 & 5.3 & 21 & 28.0 \\
\hline Non-formal & 26 & 34.7 & 9 & 12.0 \\
\hline Total & 75 & 100 & 75 & 100 \\
\hline \multicolumn{5}{|l|}{ Household size } \\
\hline $0-5$ & 9 & 12.0 & 41 & 54.7 \\
\hline $6-11$ & 47 & 62.7 & 34 & 45.3 \\
\hline $12-17$ & 18 & 24 & - & - \\
\hline $18-23$ & 1 & 1.3 & - & - \\
\hline Total & 75 & 100 & 75 & 100 \\
\hline Mean & 9.38 & & 5.22 & \\
\hline Co-eff of variation & 0.40 & & 0.58 & \\
\hline \multicolumn{5}{|l|}{ Experience (years) } \\
\hline $1-20$ & 25 & 33.3 & 60 & 80 \\
\hline $21-40$ & 29 & 38.7 & 12 & 16 \\
\hline $41-60$ & 16 & 21.3 & 3 & 4 \\
\hline $61-80$ & 5 & 6.7 & - & - \\
\hline Total & 75 & 100 & 75 & 100 \\
\hline Mean & 30.8 & & 15.3 & \\
\hline Co-eff of variation & 0.59 & & 073 & \\
\hline \multicolumn{5}{|c|}{ Membership of association } \\
\hline Member & 27 & 36 & 37 & 49.3 \\
\hline Non-member & 48 & 64 & 38 & 50.7 \\
\hline Total & 75 & 100 & 75 & 100 \\
\hline \multicolumn{5}{|c|}{ Other sources of income } \\
\hline Yes & 40 & 53.3 & 58 & 77.3 \\
\hline No & 35 & 46.7 & 17 & 22.7 \\
\hline Total & 75 & 100 & 75 & 100 \\
\hline
\end{tabular}

Source: Field survey, 2010

The Table shows that most of the fruit and vegetable respondents were male (82.7\% and $70.7 \%)$, respectively, while few were females $(17.3 \%$ and $29.3 \%)$ respectively. This implies that more males are into fruit and vegetable farming 
than females. This may be as a result of the labour intensive nature of the enterprise which could be very hectic and time consuming, especially for females who would have to combine this activity with their domestic chores. Also, fruits are usually produced on large hectares of land in combination with other permanent tree crops. Hence, it is worthy of note, that majority of these hectares of land are family farms which are usually inherited. It is only in exceptional circumstances, will these farms be inherited by a female.

Most of the fruit respondents are married (90.7\%) and only (9.3\%) are single, most of which are widows. Also, most of the vegetable respondents are married (77.3\%) and only few are not married (22.7\%). All the fruit respondents were within 21-100 years age bracket and all the vegetable respondents were within 21-60 years age bracket. Majority of the fruit respondents fall within the age bracket, 41-60 years representing (45.3\%). Majority of the vegetable respondents fall within the age bracket, 21-40 years (61.3\%). This indicates that there is a bright future for vegetable farming in the study area if, the potential of these youths are properly harnessed. A worrisome situation, however, is the presence of a large number of fruit respondents in the age bracket $61-80$ (37\%). The implication of this, is that many of these fruit farmers are ageing and this could be counterproductive.

The Table also indicates that very few (4\%) of the fruit respondents have had education up to tertiary level; while (23\%) had primary education (22\%) had secondary education and (26\%) had no formal education. On the other hand, half of the vegetable respondents (50.7\%) have up to secondary education; some (28\%) have tertiary education; few (21\%) have no formal education while very few $(9.3 \%)$ have primary education. This implies that many of the fruit and vegetable respondents have had considerable level of formal education background that could enhance human capital development. Most of fruit respondents (62.27\%) have family members that comprised 6-11 persons yet, they still employ hired labour thus, confirming the hectic and time consuming nature of the enterprise. Also, just over half of the vegetable respondents (54.7\%) have families that comprised 0 -members while the remaining respondents (45.3\%) have families that comprised 6-11 members.

The average year of involvement in fruit farming was found to be 30.8 years and that of vegetable farming was found to be 15.3 years. What this indicates is that, both the fruit and vegetable respondents are well experienced in their respective enterprise. A total of 27 fruit respondents (36\%) were members of association while a total of 48 fruit respondents (64\%) were non-members of association. Of the 27 members of association, 25(92.6\%) belong to thrift and 
savings societies while 2 (7.4\%) belong to production and marketing societies. Also, of the 48 non-members of association, 9(18.75\%) were not aware, 15(31.25\%) opted out, 20(41.67\%) were not interested, while 4(8.33\%) maintained that this association were not available for the vegetable respondents, a total of 37 respondents (49.3\%) belong to association while a total of 38 respondents (50.7\%) were non-members of the association. Of the 37 members of association, 7(18.9\%) belong to multipurpose societies, 23(62.2\%) belong to thrift and savings while $7(18.9 \%)$ belong to production and marketing. Also, of the 38 non-members of association, 24(63.2\%) were not interested, 7(18.4\%) were not aware while $7(18.4 \%)$ opted out. Table 5 also showed that $(53.3 \%)$ of the fruit respondents had other sources of income other than fruit farming while (46.7\%) rely solely on fruit farming for their livelihood. For vegetable respondents, (77.3\%) had other sources of income other than vegetable farming while (22.7\%) rely solely on vegetable farming as their major occupation.

\section{Production resources}

Here, some production information were examined and discussed as follows;

Table 3. Total area of land cultivated by respondents.

\begin{tabular}{|c|c|c|c|c|c|}
\hline \multirow{2}{*}{ Area(Ha) } & \multicolumn{2}{|c|}{ Fruit } & \multirow{2}{*}{ Area (ha) } & \multicolumn{2}{|c|}{ Vegetable } \\
\hline & Frequency & Percentage & & Frequency & Percentage \\
\hline $1-5$ & 47 & 62.7 & $0.1-3.0$ & 67 & 89.3 \\
\hline $6-10$ & 17 & 22.7 & $3.1-6.0$ & 5.0 & 8.0 \\
\hline $11-15$ & 11 & 14.6 & $6.1-9.0$ & 3.0 & 2.7 \\
\hline Total & 75 & 100 & & 75 & 100 \\
\hline Mean & & 5.36 & & & 2.21 \\
\hline Co-eff of variation & & 0.65 & & & 79 \\
\hline
\end{tabular}

Source: Field survey, 2010

Table 3 revealed that over half of the fruit respondents (62.7\%) cultivated areas of land ranging between 1 and 5 hectares, while (22.7\%) cultivated land area between 6-10 hectares and (14.6\%) cultivated between 11-15 hectares. The Table also revealed that majority of the vegetable respondents (89.3\%) cultivated on a small land area, 0.1-3.0 hectares while few (8\%) and very few (2.7\%) cultivated on 3.1-6.0 and 6.1-9.0 hectares, respectively. 
Table 4. Modes of acquisition of land used by respondents.

\begin{tabular}{|c|c|c|c|c|}
\hline \multirow{2}{*}{$\begin{array}{l}\text { Modes of } \\
\text { acquisition }\end{array}$} & \multicolumn{2}{|c|}{ Fruit } & \multicolumn{2}{|c|}{ Vegetable } \\
\hline & Frequency & Percentage & Frequency & Percentage \\
\hline Rented & 9 & 12 & 37 & 49.3 \\
\hline Inherited & 56 & 74.7 & 18 & 24 \\
\hline Purchased & 10 & 13.3 & 2 & 2.7 \\
\hline Borrowed & - & - & 11 & 14.7 \\
\hline Community land & - & - & 7 & 9.3 \\
\hline Total & 75 & 100 & 75 & 100 \\
\hline
\end{tabular}

Source: Field Survey, 2010

Table 4 revealed that majority of the land acquired by the fruit respondents (74.7\%) were inherited, while $(12 \%$ and $13.3 \%)$ of the respondents rented and purchased land respectively. None of the fruit respondents used borrowed or community land. For the vegetable respondents, (49.3\%) rented their land, (24\%) inherited the land, (14.7\%) borrowed the land, (9.3\%) made use of community land while only $(2.7 \%)$ purchased their land. The reason why more vegetable respondents acquire their land through renting as opposed to the fruit respondents is obvious. Vegetable take short period to mature and so the producer can afford to rent the land, cultivate it as well as relinquish it on demand by the owner. This is not possible with the fruit producer, who has to wait several years before he harvest his first crop.

Table 5. Type of crops produced by respondents.

\begin{tabular}{|c|c|c|c|c|c|c|}
\hline Crops & Fruit & Frequency & Percentage & Vegetable & Frequency & Percentage \\
\hline Banana & & 49 & 65.3 & $\begin{array}{l}\text { Amaranthus } \\
\text { (tete) }\end{array}$ & 54 & 72 \\
\hline Orange & & 72 & 96 & Ewedu & 54 & 72 \\
\hline Mango & & 23 & 30.7 & Okra & 59 & 78.7 \\
\hline Agbalumo & & 34 & 45.3 & Tomatoes & 20 & 26.7 \\
\hline Tangerine & & 13 & 17.3 & Pepper & 8 & 10.7 \\
\hline Cashew & & 7 & 9.3 & Melon & 4 & 5.3 \\
\hline \multirow[t]{2}{*}{ Pineapple } & & 3 & 4 & Sokoyokoto & 3 & 4 \\
\hline & & & & Pumpkin & 3 & 4 \\
\hline
\end{tabular}

Source: Field Survey, 2010

Table 5 showed that Orange (96\%), is the most widely grown fruit crop in the study area, followed by Banana (65.3\%), Agbalumo (45.3\%), Mango (30.7\%), Tangerine (17.3\%), Cashew (9.3\%) and Pineapple (4\%). The Table 
showed that Okra (78.7\%), is the most widely grown vegetable crop in the study area, closely followed by Amaranthus (Tete) and Ewedu, (72\%) each. Other crops include Tomatoes (26.7\%), Pepper (10.7\%), Melon (5.3\%), Sokoyokoto (4\%) and Pumpkin (4\%). It is worthy of note however, that these crops are grown either in mixed cropping with one another or with other crops.

Table 6. Modes of marketing of produce.

\begin{tabular}{l|l|lll|l}
\hline \multicolumn{3}{c|}{ Modes of marketing } & \multicolumn{2}{c}{ Vegetable } \\
\hline \multicolumn{1}{c}{ Fruit } & Frequency & Percentage & Frequency & Percentage \\
\hline Direct to consumer & 17 & 22.7 & 20 & 26.7 \\
Middlemen & 45 & 60.0 & 24 & 32.0 \\
Both direct and middle & 13 & 17.3 & 31 & 41.3 \\
Total & $\mathbf{7 5}$ & $\mathbf{1 0 0}$ & $\mathbf{7 5}$ & $\mathbf{1 0 0}$ \\
\hline
\end{tabular}

Source: Field Survey, 2010

The Table showed that, majority of the fruit respondents (60\%) market their produce through middlemen while $(41.3 \%)$ of the vegetable respondents market their produce through both direct to consumer and middlemen.

\section{Discriminant analysis}

Discriminant analysis was used to determine the risk attitude as well as examine the factors influencing the attitude of respondents towards risk in fruit and vegetable farming.

Table 7. Classification of fruit farmers into groups based on their attitude towards risk.

\begin{tabular}{l|l|l|l|l}
\hline \multirow{2}{*}{ Group } & \multirow{2}{*}{ True group } & \multicolumn{3}{c}{ Predicted group } \\
\cline { 3 - 5 } & & Risk averse & Risk neutral & Risk taker \\
\hline Risk averse & 34 & 18 & 6 & 10 \\
Risk neutral & 23 & 3 & 18 & 2 \\
Risk taker & 18 & 3 & 2 & 13 \\
Total & 75 & 24 & 26 & 25 \\
\hline
\end{tabular}

$65.3 \%$ of the original grouped cases correctly classified.

Source: Field survey, 2010 
Table 8. Classification of vegetable farmers into groups on their attitude towards risk.

\begin{tabular}{l|l|l|l|l}
\hline \multirow{2}{*}{ Group } & \multirow{2}{*}{ True group } & \multicolumn{3}{c}{ Predicted group } \\
\cline { 3 - 5 } & & Risk averse & Risk neutral & Risk taker \\
\hline Risk averse & 36 & 19 & 9 & 8 \\
Risk neutral & 20 & 2 & 13 & 5 \\
Risk taker & 19 & 4 & 6 & 9 \\
Total & 75 & 25 & 28 & 22 \\
\hline
\end{tabular}

$54.7 \%$ of the original grouped cases correctly classified.

Source: Field survey, 2010

Table 7 and 8 showed the classification of farmers into true and predicted groups based on their attitude to risk, (risk averse, risk neutral and risk taker). By using discriminant analysis, we were able to classify farmers based on their attitude to risk, that is, predicted group given the true group. For the fruit respondents, 24 belonged to the risk averse group, 26 belonged to the risk neutral group while 25 respondents were risk takers. Similarly for the vegetable respondents, 25 respondents were risk averse, 28 respondents were risk neutral while the remaining 22 respondents were risk takers.

Table 9. Linear discriminant function for groups in fruit farming.

\begin{tabular}{lllll}
\hline Discriminating variables & Risk averse & Risk neutral & Risk taker \\
\hline Constant & -49.709 & -55.657 & -50.885 \\
Experience (X1) & -0.046 & -0.077 & -0.088 \\
Education status (X2) & -0.715 & -0.969 & -0.512 \\
Household size (X3) & -0.056 & 0.109 & -0.032 \\
Total area cultivated (X4) & 0.362 & 0.419 & 0.567 \\
Other sources of income (X5) & -3.540 & -6.204 & -2.141 \\
Membership of association (X6) & 11.331 & 12.935 & 11.792 \\
Estimated expenditure/month (X7) & 0.000 & 0.000 & 0.000 \\
Proportion of farm income to total income & 66.026 & 70.760 & 63.903 \\
(X8) & & & \\
Availability of storage facilities (X9) & 4.792 & 7.331 & 5.889 \\
Gender (X10) & 14.946 & 14.155 & 13.716 \\
\hline
\end{tabular}

Source: Field survey, 2010

Table 9 showed that 5 of the 10 discriminating variables influenced farmers' attitude towards risk in fruit and vegetable farming. These variables include other 
sources of income, membership of association, proportion of farm income to total income, availability of storage facilities and gender. While other sources of income had a negative influence on farmers' attitude, the remaining 4 factors had a positive influence on farmers' risk attitude.

Table 10. Linear discriminant function for groups in vegetable farming.

\begin{tabular}{lllll}
\hline \multicolumn{1}{c}{ Discriminating variables } & Risk averse & Risk neutral & Risk taker \\
\hline Constant & -36.535 & -34.396 & -36.892 \\
Experience (X1) & -0.100 & -0.124 & -0.054 \\
Education status (X2) & 5.119 & 4.946 & 5.638 \\
Household size (X3) & 1.096 & 1.051 & 0.860 \\
Total area cultivated (X4) & 0.691 & 0.729 & 0.866 \\
Other sources of income (X5) & 4.528 & 5.190 & 3.859 \\
Membership of association (X6) & 7.767 & 7.721 & 8.377 \\
Estimated expenditure/month (X7) & 0.000 & 0.000 & 0.000 \\
Proportion of farm income to total income & 19.843 & 18.982 & 20.275 \\
(X8) & & & \\
Availability of storage facilities (X9) & 3.044 & 4.212 & 2.580 \\
Gender (X10) & 11.157 & 9.099 & 11.015 \\
\hline
\end{tabular}

Source: Field survey, 2010

Table 10 showed that 7 of the 10 discriminating variables influence farmers' attitude towards risk in vegetable farming. These variables include education status, household size, other sources of income, membership of association, proportion of farm income to total income, availability of storage facilities and gender.

\section{Farmers' perception on major sources of risk in fruit and vegetable farming}

The farmer's perception on major sources of risk was summarized under two broad groups namely; Production and Market Risks. Thus, by using KruskalWallis One Way Analysis of Variance (ANOVA) by ranks, the major sources of risk as perceived by the respondents were ranked from $1-10$. With 1 and 10 representing the lowest and highest ranked sources of risk respectively as shown by Table 11 and 12 . 
Table 11. Summary of Kruskal-Wallis test for major sources of production risk.

\begin{tabular}{l|c|c|c|c}
\hline \multirow{2}{*}{\multicolumn{1}{c|}{ Sources }} & \multicolumn{2}{c|}{ Fruit } & \multicolumn{2}{c}{ Vegetable } \\
\cline { 2 - 6 } & Mean & Rank & Mean & Rank \\
\hline Damage by pest and disease & 532.27 & 10 & 420.18 & 8 \\
Expensive inputs & 409.84 & 7 & 405.37 & 7 \\
Lack of technical knowledge in production and & 226.61 & 2 & 268.79 & 2 \\
processing & & & & \\
High cost of production & 380.76 & 4 & 388.76 & 6 \\
Infrastructural bottlenecks & 286.56 & 3 & 261.71 & 1 \\
Weak research and extension agents & 381.51 & 5 & 365.23 & 4 \\
Traditional methods of farming & 493.41 & 9 & 467.93 & 9 \\
Weather dependency & 437.51 & 8 & 514.05 & 10 \\
Poor productivity & 207.13 & 1 & 278.44 & 3 \\
High post harvest losses & 399.39 & 6 & 384.54 & 5 \\
Chi-square & 196.678 & & 117.932 & \\
Degree of freedom & 9 & & 9 & \\
Asymp. Sig. & .0001 & & .0001 & \\
\hline
\end{tabular}

1 - 10: Lowest to Highest

Source: Computer printout, 2010.

Table 11 showed that damage by pest and disease (mean 532.27), traditional methods of farming (mean 493.41) and weather dependency (mean 437.51) were the highest ranked sources of production risk as perceived by the fruit respondents while poor productivity (mean 207.13), lack of technical knowledge in production and processing (mean 226.61) and infrastructural bottlenecks (mean 286.56) were perceived as the lowest ranked sources of production risks by the fruit respondents. The Table also showed that weather dependency (mean 514.05), traditional methods of farming (mean 467.93) and damage by pest and disease (mean 420.18) were perceived as the highest ranked sources of risk in production by the vegetable respondents while infrastructural bottlenecks (mean 261.71), lack of technical knowledge in production and processing (mean 268.79) and poor productivity (mean 278.44) were perceived as the lowest ranked risk sources by the vegetable respondents. The Table also showed that all the sources of risk in production of both the fruit and vegetable respondents were significant at all levels and that they are statistically different from one another. 
Table 12. Summary of Kruskal-Wallis test for major sources of market risk

\begin{tabular}{l|ll|cc}
\hline \multirow{2}{*}{\multicolumn{1}{c}{ Sources }} & \multicolumn{3}{c|}{ Fruit } & \multicolumn{2}{c}{ Vegetable } \\
\cline { 2 - 6 } & Mean & Rank & Mean & Rank \\
\hline Perishability of produce & 488.51 & 9 & 531.95 & 10 \\
Low price of produce & 492.81 & 10 & 507.57 & 9 \\
High marketing cost & 393.47 & 6 & 256.27 & 1 \\
Lack of discriminating pricing systems based on & 337.47 & 4 & 389.90 & 7 \\
quality and grades of produce & & & \\
Lack of coordination among producers to increase & 355.67 & 5 & 380.47 & 6 \\
bargaining power & & & & \\
Exploitation by middlemen or many middlemen & 470.01 & 8 & 372.96 & 5 \\
Poor product handling and packaging & 446.85 & 7 & 422.89 & 8 \\
Lack of market information & 267.50 & 3 & 298.59 & 3 \\
Poor market linkages & 266.55 & 2 & 313.64 & 4 \\
Lack of markets to absorb production & 236.22 & 1 & 280.75 & 2 \\
Chi-square & 163.204 & & 142.016 & \\
Degree of freedom & 9 & & 9 & \\
Asymp. Sig. & .0001 & & .0001 & \\
\hline
\end{tabular}

1 - 10: Lowest to Highest

Source: Computer printout, 2010.

Table 12 reveals that low prices of produce (mean 492.81), perishability of produce (mean 488.51) and exploitation by middlemen or many men (mean 470.01) were the highest ranked sources of market risk as perceived by the fruit respondents while lack of markets to absorb production (mean 236.22), poor market linkages (mean 266.55) and lack of market information (mean 267.50) were perceived as the lowest sources of market risk as ranked by the respondents. The table also revealed that perishability of produce (mean 531.95), low price for produce (mean 507.57), poor product handling and packaging (mean 422.89) were perceived as the highest sources of market risks as ranked by the vegetable respondents while high marketing cost (mean 256.27), lack of markets to absorb production (mean 280.75) and lack of market information (mean 298.59) were the lowest ranked sources of market risk as perceived by the vegetable respondents. Similarly as with the sources of production risk, this table also showed that all the sources of market risk in both the fruit and vegetable respondents were significant at all levels and that they are statistically different from one another. 


\section{Strategies of risk management in fruit and vegetable farming}

The risk management strategies being adopted in fruit and vegetable farming have been summarized in table 13 .

Table 13. Risk management strategies in fruit and vegetable farming.

\begin{tabular}{l|lll|l|l}
\hline \multirow{2}{*}{\multicolumn{1}{c|}{ Strategies }} & \multicolumn{3}{c|}{ Fruit } & \multicolumn{3}{c}{ Vegetable } \\
\cline { 2 - 5 } & Response & Percentage & Response & Percentage \\
\hline Adoption of new farming techniques & 14 & 18.7 & 26 & 34.7 \\
Crop planning and time management & 51 & 68.0 & 48 & 64 \\
Crop diversification & 64 & 85.3 & 51 & 68 \\
Processing of produce for better prices & 5 & 6.7 & 13 & 17.3 \\
Sell within their locality & 66 & 88.0 & 69 & 92.0 \\
Sell at low prices due to perishability & 68 & 90.7 & 46 & 61.3 \\
Maintain good relations with traders & 75 & 100 & 70 & 93.3 \\
Non-farm businesses & 40 & 53.3 & 58 & 77.3 \\
\hline
\end{tabular}

Source: Field survey, 2010

Table 13 showed the response of all the fruit and vegetable farmers to each of the risk management strategies. The table showed that all the fruit respondents (100\%) maintained good relationship with traders as an effective risk management strategy. This was closely followed by selling at low prices due to perishability (90.7\%) and selling within their locality (88.0\%). 64 respondents (85.3\%) engage in crop diversification while crop planning and time management (68\%), non-farm businesses (53.3\%) and adoption of new farming techniques $(18.7 \%)$ followed in that order. However, only few of the respondents (6.7\%) engage in the processing of their produce for better prices. This may be due to lack of adequate technical know-how and techniques required for the processing of fruit for better prices. It may also be due to lack of funds necessary to purchase appropriate equipment for processing.

Similarly, the Table revealed that majority of the vegetable respondents (93.3\%) maintained good relationship with traders as an effective risk management strategy. But this time, it was closely followed by selling within the locality $(92.0 \%)$ and non-farm businesses (77.3\%). (68\%) of the respondents engage in crop diversification as a way of minimizing risk while crop planning and time management (64\%), sell at low prices due to perishabiliity (61.3\%) and adoption of new farming techniques (34.7\%) followed in that order. Similarly, processing of produce for better prices (17.3\%) as a means of managing risk is low with the vegetable respondents. 


\section{Conclusion and Recommendations}

The study examined the risks associated with fruit and vegetable farming in Osun state, Nigeria. The study showed that damage by pest and disease and traditional methods of farming are the two most perceived sources of production risk in the study area. As such, improved subsidy packages for agricultural inputs like insecticides and pesticides would go a long way in combating these sources of risk. It was also shown that the perishability of produce and low price of produce are the most perceived sources of market risk in the study area. Hence, provision of storage facilities would ensure that these produce are processed, stored and sold at better prices. It is also necessary to reduce risks and uncertainties in fruit and vegetable farming through the introduction of a more comprehensive agricultural insurance scheme. This is more so considering the amount of risks experienced by respondent farmers

Awareness on the nutritional benefit of consumption of $400 \mathrm{~g} / \mathrm{head} /$ day of fruit and vegetable as recommended by the World Health Organization (WHO) should be enhanced in a similar fashion as the awareness created for consumption of an egg/day. Efforts should be stepped up at introducing to farmers, relevant improved technologies such as tissue culture banana technology. This technology had been proven to be successful in Kenya. It is suitable for remedying the problems of declined banana productivity emanating from soil borne diseases and pests infestation. The technology allows plants to mature early and uniformly such that farmers are able to harvest and sell fairly large quantities at a time. Finally, public intervention can facilitate better risk management through improved information system.

\section{References}

Fakayode, S. B, R.O. Babatunde, S. T Olowogbon and W. S Adesuyi. 2010. An Appraisal of Beekeeping Activities among Beneficiaries and Non-Beneficiaries of Ekiti State Agricultural Credit Agency (ESACA) Scheme in Nigeria. Paper presented at the $3^{\text {rd }}$ Annual African Association of Agricultural Economists (AAAE) $/ 49^{\text {th }}$ Annual Agricultural Economists Association of South Africa (AEASA) conference held between $19^{\text {th }}-23^{\text {rd }}$ September, 2010, at the Westin Grand. CapeTown Arebella Quays. South Africa. Available online at www.agrecon Adesuyi, W.S. (2009): "Comparative Assessment of Beekeeper Beneficiaries and Nonbeneficiaries of ESACA scheme". A Project submitted to the Department of Agricultural Economics and Farm management, University of Ilorin, Ilorin, Nigeria

Adeyemi, S.A.O. and P.O. Ogazi. 1983. "Fruit and Vegetable Processing”. A Seminar Presented on Agro-based industrialization held at ASCON, Badagry, Nigeria; $14^{\text {th }}$ November $-3^{\text {rd }}$ December, 1983. Pp 7.

Ajekigbe, J. M. 2007. "Financial Intermediation for Unlocking Potentials in Nigeria". Power Point Presentation. First Bank of Nigeria. 
Aseogwu, S.N. 1989. “The Industrial Potentials of some Nigeria Fruits and Vegetables”. Occasional Paper No.20 NIHORT Pg 1.

Ayorinde, K.L. 2005. “Agricultural Development Option as a Tool to fight Hunger and Unemployment: The Kwara state Approach". Presentation at the National War College $14^{\text {th }}$ Geostrategic Tour to Kwara state, Conference room, Governor's office, Ilorin. 17pp.

Babatola, J.O. 2004. “Export Promotion of Horticultural Crops”. A paper presented at the Proceeding of Annual Conference of Horticultural Society of Nigeria.

Klecka, W.R. 1980. "Discriminant Analysis Series: Quantitative Applications in the Social Sciences. SAGE publications inc. California, U.S.A.

Macmillian Nigeria Secondary Atlas. 2006. Macmillian Nigeria Publishers Limited.

Manyong, V.M., Ikpi, A., Olayemi, J.K., Yusuf, S.A., Omonona, R. and Idachaba,F.S. 2003. "Agriculture in Nigeria: Identifying opportunities for increased Commercialization and Investment”. Main Report from International Institute for Tropical Agriculture (IITA) and University of Ibadan (UI) for United State Agency for International Development (USAID)/Nigeria.

Okigbo, B.N. 1977. "Neglected Plants of Horticultural and Nutritional Importance in Traditional Farming System of Tropical Africa”. ISHS Acta Horticulturae 53:IV African Symposium on Horticultural Crops.

Okigbo, B.N. 1983. "Fruits and Vegetable Production and Extension Services in Africa”. ISHS Acta Horticulturae 123: VI African Symposium on Horticultural Crops.

Okigbo, B.N. 1988. “Large Scale Agriculture and Integrated Agro-industries”. In Giant Strides. Lagos VBO International Limited. Vol. 2

Oseni, T.O. 2004. "Integrated Horticultural Crop Production and Extension Services". A paper presented at the Proceeding of Annual Conference of Horticultural Society of Nigeria.

Osun state. 2009. "Agriculture”. Accessed online at www.osunstate.gov.org. February 10, 2010.

Salau, O. I. 2009. "Risk Analysis of Maize Production in Kwara state”. A Project submitted to the Department of Agricultural Economics and Farm Management, University of Ilorin, Ilorin, Nigeria.

Teknomo, K. 2006. “Discriminant Analysis Tutorial” available online at http//people.revoledu.com/kardi/tutorial/LDA.

U.S. Library of Congress. 2009. "Nigeria - Agriculture". Accessed online at www.countrystudies.US/Nigeria/58.htm.

Ullah, M.H. 1980. “Some Aspects of Economics of Citrus Cultivation”. The Punjab Fruit Journal Printing Press Limited. Bull Road, Lahore XXVI - VII (90-99):42-45/431.

Wayne, D.W. 1990. “Applied Non-parametric Statistic”. Second Edition, PNS-Kent Publishing Company, Boston. Pp 225-226.

Wikipedia, the free encyclopedia. 2009. "Osun State”. Accessed online at www.wikipedia.org. October 12, 2009. 